\title{
Antibacterial Activity of Some Seaweed Extracts against Multidrug Resistant Urinary Tract Bacteria and Analysis of their Virulence Genes
}

\author{
Wagih A. El-Shouny", Reda M. Gaafar, Gehan A. Ismail and Marwa M. Elzanaty \\ Botany Department, Faculty of Science, Tanta University, Tanta, Egypt \\ *Corresponding author
}

\begin{tabular}{|l|}
\hline K e y w o r d s \\
Antibacterial activity, \\
$\begin{array}{l}\text { PCR analysis, Ulva } \\
\text { lactuca, UTI infection, } \\
\text { Virulence genes. }\end{array}$ \\
\hline Article Info \\
\hline $\begin{array}{l}\text { Accepted: } \\
\text { 20 September } 2017 \\
\text { Available Online: } \\
\text { 10 November } 2017\end{array}$ \\
\hline \hline
\end{tabular}

\section{Introduction}

Worldwide, urinary tract infections (UTI) are among the most common infectious diseases. About 150 million people are diagnosed with UTI every year (Gonzalez and Schaeffer, 1999). A urinary tract infection is an infection involving the kidneys, ureters, bladder, or urethra. These are the structures that urine passes through before being eliminated from the body (Foxman and Brown, 2003). Virtually, an infection occurs when Gram negative bacteria (Escherichia coli, Klebsiella pneumoniae and Proteus vulgaris) get into the urine and begin to grow. The infection usually starts at the opening of the urethra, where the urine leaves the body and moves upward into the urinary tract, these bacteria normally live in the bowel (colon) and around the anus. The symptoms develop rapidly including fairly high fever, shaking chills, nausea and vomiting (Kalaivani et al., 2016). UTI infection may complicate into an acute or chronic kidney infection (pyelonephritis) or even permanent kidney damage due to neglected or not correctly treated infection. Many classes of antibiotics were classified as typical treatments for such diseases. However, the improper and uncontrolled use of many antibiotics resulted in the occurrence of 
antimicrobial drug resistance, which became a major health problem worldwide (Dethlefsen et al., 2008) and forced seeking for new treatment sources.

Virulence factors are specific traits enabling pathogenic bacteria to overcome host immune system and cause various diseases (Ejrnaes, 2011). Virulence genes are located on transmissible genetic elements and/or in particular regions on the chromosome that are called pathogenicity islands (Farshad et al., 2012). Pathogenicity islands directed coordinate horizontal transfer of virulence genes between strains of one species or even related species (Hacker et al., 1997). UTI bacterial strains have various types of virulence factors such as adhesions, hemolysin, urease enzyme, toxins and iron uptake systems that facilitate colonization and persistence of the bacteria in the urinary tract (Oliveira et al., 2011) and support their resistance system and pathogenicity to the regularly used synthetic drugs.

Nowadays, seaweeds are considered a novel source of bioactive compounds and produce a great variety of secondary metabolites exhibiting broad spectrum of biological activities (Khotimchenko et al., 2002; Ramasamy and Kumar, 2009; El-Sheekh et al., 2016). Many types of seaweed have been screened extensively to isolate natural drugs or biologically active substances from different habitats around the world. Several solvents with different polarities e.g. hexane, chloroform, ethanol, methanol, acetone and water were used to extract the antimicrobial material from such seaweeds. Compounds with cytostatic, antiviral, anthelminthic, antifungal, bacteriostatic and bactericidal activities have been detected in green, brown and red seaweeds with a comparable promising results with authentic antibiotics (Newman et al., 2003; Manikandan et al., 2011; Osman et al., 2013; Ismail et al., 2016).
Active antibacterial agents found in the seaweeds include terpenoid, phlorotannins, acrylic acid and phenolic compounds (Cardoso et al., 2014). Also, steroids, halogenated ketone, fatty acids and alkaline, cyclic polysulphides were recorded (Cheung et al., 2015; Khelil-Radji et al., 2017). The present study aimed to explore the antibacterial activity of some seaweed extracts against urinary tract (UTI) infectious bacteria. To compare the activity of these extracts as natural drug sources with the standard synthetic antibiotics against multidrug resistant (MDR) isolates. Finally, to compare the virulence gene profiles of the UTI isolates and detect the effect of seaweeds treatment on their virulence activities.

\section{Materials and Methods}

\section{Isolation and identification of bacterial isolates}

The bacterial swaps were obtained from microbiology laboratories, Faculty of Pharmacy, Tanta University, Tanta, Egypt. The bacterial isolates, generally Gram negative, were cultivated on different selective media. The morphological and biochemical examinations were conducted repeatedly according to the standard methods until complete purification and identification of these bacterial isolates (Oxoid, 1981; Collee et al., 1996). Eight bacterial isolates were selected of which Escherichia coli (3 isolates), Klebsiella pneumoniae (2 isolates) and Proteus mirabilis (3 isolates).

\section{Antibiotic susceptibility test of bacterial isolates}

The antibacterial susceptibility of the pathogenic bacterial isolates were confirmed against eight different classes of antibiotics using the modified Kirby-Bauer disk diffusion method according to the Clinical and 
Laboratory Standards Institute (CLSI, 2012) on Mueller Hinton agar. The tested antibiotics were commonly used in the treatments of UTI cases and included: Carbapenems, Cephalosporins, Monobactams, Nitrofuratoins, Penicillins, Polyketide, Quinolone/ Fluoroquinolone and Sulfonamides. The plates were then incubated overnight at $37^{\circ} \mathrm{C}$. The diameters of the inhibition zones were measured (Vasquez and Hand, 2004) and compared to differentiate the bacterial isolates into sensitive, intermediate and resistant and to calculate the multiple antibiotic resistances (MAR) index for each isolate (by dividing the number of antibiotics to which the isolate is resistant by the total number of tested antibiotics).

\section{Preparation of algal extracts}

Three species of seaweeds from different divisions (Chlorophyta) Ulva lactuca, (Phaeophyta) Petalonia fascia and (Rhodophyta) Gelidium spinosum were collected in 2016 from Abu Qir-Bay, Alexandria, Egypt (N 31 ${ }^{\circ} 19^{`}$ E $\left.30^{\circ} 03^{\prime}\right)$. The seaweeds were identified according to (Aleem, 1993) and (Guiry and Guiry, 2016). The different seaweeds were air dried in the shade at room temperature $\left(25^{\circ} \mathrm{C}\right)$ and then grounded to fine powder. The powders (1:10 w/v) were soaked with different polar organic solvents $(80 \%$ each of ethanol, methanol and acetone in addition to water) for 24 hrs.on a rotary shaker at $150 \mathrm{rpm}$. The extracts from three consecutive soakings were pooled together and filtered. The obtained filtrates were evaporated using rotary evaporator at $45^{\circ} \mathrm{C}$ until dryness, then weighed and stored at $-20^{\circ} \mathrm{C}$ (Karthikaidevi et al., 2009). The collected seaweeds were identified to be:

\section{Ulva lactuca Linnaeus}

Empire: Eukaryota, Kingdom: Plantae, Phylum: Chlorophyta, Class: Ulvophyceae,
Order: Ulvales, Family: Ulvaceae Genus: Ulva.

\section{Petalonia fascia (O. F. Müller) Kuntze}

Empire: Eukaryota, Kingdom: Chromista, Phylum: Ochrophyta, Class: Phaeophyceae, Order: Ectocarpales, Family: Scytosiphonaceae, Genus: Petalonia.

Gelidium spinosum (S. G. Gmelin) P.C. Silva.

Empire: Eukaryota, Kingdom: Plantae, Phylum: Rhodophyta, Class: Florideophyceae, Order: Gelidiales, Family: Gelidiaceae, Genus: Gelidium.

\section{Antibacterial activity test of seaweeds extracts}

The seaweeds antibacterial activity was assayed using disk diffusion method as described in the previous section. Suspensions of the tested bacterial isolates were prepared from overnight freshly incubated bacterial cultures and mixed in sterilized saline solution $(0.9 \% \mathrm{w} / \mathrm{v} \mathrm{NaCl})$ to get cell counts of $10^{6}$ to $10^{8} \mathrm{CFU} / \mathrm{ml}$ for each bacterial isolate (Gilbert, 1987).

Seaweed extract was prepared by resuspending the powder $(50: 1 \mathrm{w} / \mathrm{v})$ in each solvent. Previously sterilized filter paper disks were immersed in different algal extracts $(20$ $\mu 1)$ and inoculated over Petri dishes surface. The plates were incubated for 2 hours at $4^{\circ} \mathrm{C}$ to allow the diffusion of antibacterial substance and then incubated overnight at $37^{\circ} \mathrm{C}$. Standard antibiotic discs and solvent discs were used as positive and negative controls, respectively.

The diameter of inhibition zones indicates the antibacterial activity of different seaweeds in different solvents. 


\section{Identification of sensitive bacterial isolates}

Bacterial isolates which were sensitive to seaweed extracts were identified using Biomerieux VITEK ${ }^{\circledR}$ system. The Biomerieux VITEK®2 cards were filled with the tested bacterial suspension and manually loaded into the VITEK®2 system for identification (Thomas et al., 2001 ).

\section{Fractionation, purification and characterization of antibacterial crude extracts}

\section{Column chromatography and UV spectra of algal antibacterial agent}

Active crude seaweed extract (5 g) was purified and fractioned by column chromatography on silica gel G EDWC, 60200 mesh (Solomon and Santhi 2008). A glass column $(3 \mathrm{~cm} \times 20 \mathrm{~cm})$ was packed by silica gel (30-40 g) in pure chloroform eluted with gradients of mobile phase from 30:70\% chloroform: ethanol to $70: 30 \%$ chloroform: ethanol and the collected fractions were evaporated at $40^{\circ} \mathrm{C}$ under vacuum. The dried fractions were dissolved in $70 \%$ ethanol solvent and their absorption was measured using UV spectrophotometer (UV 2101/pc) at 200- $900 \mathrm{~nm}$ wavelength (Blunt et al., 2007). The antibacterial activity of the collected fractions was examined against UTI bacterial isolates using disk diffusion method. Different active fractions with the same UV absorption were collected together, dried and subjected to subsequent analysis to determine the chemical structure of the active compounds.

\section{Infra-red spectra (IR) of the algal antibacterial agent}

The infra-red spectrophotometer (FT-IR) (Perkin Elmer 1430) was used to identify the functional groups of the antibacterial algal material (Boeriu et al., 2004). The pellet which contains sample of active compound in solid phase was mixed with $\mathrm{KBr}$ (FT-IR grade) and FT-IR spectra were recorded in the range of 4000- $400 \mathrm{~cm}^{-1}$.

Proton nuclear magnetic resonance $\left({ }^{1} \mathrm{H}\right.$ NMR) spectra of algal antibacterial agent

The sample was mixed with dehydrated chloroform solvent $(0.04 \mathrm{~g} / \mathrm{ml})$. Different protons of the antibacterial material could be identified by their corresponding nuclear magnetic resonance (Atalah et al., 2007).

\section{Gas chromatography mass spectrometry (GC-MS)}

Gas chromatography mass spectrometry (GCMS) analysis was used to determine the chemical composition of the seaweeds antibacterial material. The acquisition parameters were done with column $(30 \mathrm{~m} \mathrm{x}$ $250 \mu \mathrm{m} \times 0.25 \mu \mathrm{m}$ film thickness) using helium as carrier gas $(0.8 \mathrm{ml} / \mathrm{min})$ with Perkin Elmer: Clarus 580/560 S model system. The $\mathrm{GC}$ oven temperature was programed from $60^{\circ} \mathrm{C}$ to $250^{\circ} \mathrm{C}$ at a rate of $2^{\circ} \mathrm{C} / \mathrm{min}$. Relative area values (as a percentage of total volatile composition) were directly obtained from total ion current (TIC).

\section{Molecular detection of the virulence factors} of the bacterial strains

\section{DNA extraction and PCR amplification of virulence factors}

In order to extract genomic DNA of the multidrug resistant (MDR) bacterial isolates, which were sensitive to the seaweeds antibacterial material, boiling method was used. Before DNA extraction, the bacterial isolates were activated by overnight culturing on nutrient broth at $37^{\circ} \mathrm{C}$, then it was centrifuged at $5 \times 10^{3}$ for 15 minutes. The resulted pellets were mixed in $100 \mu \mathrm{l}$ of sterilized water and incubated in boiling water 
for $10 \mathrm{~min}$ at $100^{\circ} \mathrm{C}$ for complete DNA extraction (Anderson et al., 2004). Polymerase chain reaction (PCR) technique was used to detect three virulence factors genes including hemolysin, adhesion and urease.

Amplification of bacterial virulence genes was done in a total volume of $25 \mu 1$ containing $1 \mu \mathrm{l}$ of bacterial suspension, $1.5 \mu \mathrm{l}$ of each of the primers, $8.5 \mu 1$ sterilized distilled water, and $12.5 \mu \mathrm{l}$ of the red master mix (Bioline); which contained $1000 \times 50 \mu 1$ Reactions U Taq DNA polymerase (SigmaAldrich) in $1 \times$ PCR buffer containing $1.5 \mathrm{mM}$ $\mathrm{MgCl}_{2}$ (Table 1).

Table.1 Sequences of the primers used to amplify the UTI virulence genes

\begin{tabular}{|c|c|c|c|}
\hline Primer & Sequence $\left(5{ }^{\prime}-3\right)$ & Amplicon size (bp) & Annealing Temp. \\
\hline \multicolumn{4}{|c|}{ Hemolysin } \\
\hline HpmA F & 5-GTTGAGGGGCGTTATCAAGAGTC-3’ & 709 & $55^{\circ} \mathrm{C}$ \\
\hline HpmA R & 5'-GATAACTGTTTTGCCCTTTTGTGC-3' & & \\
\hline \multicolumn{4}{|c|}{$\begin{array}{ll}\text { Adhesin } \\
\end{array}$} \\
\hline UcaA F & 5`GTAAAGTTGTTGCGCAAAC-3` & 580 & $50^{\circ} \mathrm{C}$ \\
\hline UcaA R & 5-TTGAGCCACTGTGGATACA-3` & & \\
\hline \multicolumn{4}{|c|}{$\begin{array}{ll}\text { Urease } \\
\end{array}$} \\
\hline UreC F & 5-CCGGAACAGAAGTTGTGGCT-3` & 533 & $63^{\circ} \mathrm{C}$ \\
\hline UreC R & 5-GGGCTCTCCTACCGACTTGA-3` & & \\
\hline
\end{tabular}

PCR conditions were adjusted as following: the initialization heating step was done at $95^{\circ} \mathrm{C}$ for $3 \mathrm{~min}$, and then a denaturation step at $95^{\circ} \mathrm{C}$ for $50 \mathrm{sec}$. followed by an annealing step at $55^{\circ} \mathrm{C}$ for $50 \mathrm{sec}$. The elongation step was performed at $72^{\circ} \mathrm{C}$ for $30 \mathrm{sec}$. These steps were repeated 35 times (cycles). The final elongation was performed at $72^{\circ} \mathrm{C}$ for 6 min. in a Thermo cycler apparatus (HVD S-96).

The PCR products were electrophoresed on $1 \%$ agarose gels. The gels were stained in ethidium bromide for $15 \mathrm{~min}$. and visualized under UV-transilluminator (UVP Photo-DocIt Imaging system). The size of the amplicons was determined by comparing them with the 1 kb DNA ladder (Thermo scientific) included on the same gel (Johnson, 1991).

\section{Statistical analysis}

All experiments were done in triplicates and the results were expressed as means \pm standard deviation (SD). Analysis of variance (ANOVA one way) was established to assess the significant variation in antibacterial activities of different seaweed extracts on the tested bacterial isolates at $P \leq 0.05$ level of significance.

\section{Results and Discussion}

\section{Antibiotic susceptibility test of bacterial isolates}

Synthetic antibiotics, by its own, constitute a global growing problem due to their many harmful side effects. Indiscriminate use of antibiotics to treat such infectious diseases increased the bacterial pathogenicity and resistance to these medications creating multidrug resistant strains (Read and Woods 2014). UTI diseases have become one of the leading causes of death worldwide especially when miss diagnosed or improperly treated. 
The multi-antibiotics resistance MAR index results revealed that all tested urinary tract isolates $E$. coli (3 isolates), K. pneumoniae (2 isolates) and $P$. mirabilis (3 isolates) had a very high MAR index value (>0.2) with resistance values ranged from $63 \%$ to $100 \%$ (Table 2). According to (Olayinka et al., 2009), the MAR values are an indication of the degree of microbial exposure to specific antibiotics used within the community. It is usually used to test the resistance of antibiotic and to analyze health risk parameters. In this concern, they also showed high incidence multiple drug resistance (MDR) capacity of 5 to 9 antibiotic agents. The bacterium, which is simultaneously resistant to a number of antibiotics belonging to different chemical classes is indicated to be MDR (Magiorakos et al., 2012).
Therefore, discovering new naturally antimicrobial compounds from seaweeds with various chemical structures and different mechanisms of action appears a promising approach. Seaweeds are abundant and famed with their healthy nutritional values around the world. Nowadays, seaweeds were rediscovered as cheap and safe sources in many medicinal and pharmacological applications (Adaikalaraj et al., 2012). Regarding the calculated results of the multiple antibiotics resistance (MAR) index (Table 2), E1 isolate of Escherichia coli, $\mathrm{K} 1$ isolate of Klebsiella pneumoniae and P1 isolate of Proteus mirabilis were selected as the most multidrug resistant (MDR) bacterial isolates for testing the antibacterial activities of the seaweed extracts and for PCR analysis of the bacterial virulence genes.

Table.2 The antibiotic susceptibility test of bacterial isolates against different antibiotics

\begin{tabular}{|c|c|c|c|c|c|c|c|c|c|c|}
\hline \multirow{2}{*}{$\begin{array}{l}\text { Antibiotic } \\
\text { class }\end{array}$} & \multirow[t]{2}{*}{ Antibiotics common name } & \multirow{2}{*}{$\begin{array}{l}\text { Potency } \\
\mu \mathrm{g} / \mathrm{disk}\end{array}$} & \multicolumn{8}{|c|}{ Bacterial isolates } \\
\hline & & & E1 & E2 & E3 & K1 & $\mathbf{K 2}$ & P1 & $\mathbf{P 2}$ & P3 \\
\hline Carbapenems & Imipenem (IMP) & 10 & $\mathrm{~S}$ & I & $\mathrm{S}$ & $\mathrm{S}$ & $\mathrm{S}$ & $\mathrm{R}$ & $\mathrm{S}$ & $\mathrm{S}$ \\
\hline Cephalosporin & Ceftazidime (CAZ) & 30 & $\mathrm{R}$ & $\mathrm{R}$ & S & $\mathrm{R}$ & S & $\mathrm{R}$ & $\mathrm{R}$ & $\mathrm{R}$ \\
\hline Monobactams & Aztreonam (ATM) & 10 & $\mathrm{R}$ & $\mathrm{R}$ & $\mathrm{R}$ & $\mathrm{R}$ & $\mathrm{R}$ & $\mathrm{R}$ & $\mathrm{R}$ & $\mathrm{R}$ \\
\hline Nitrofuratoins & Nitrofurantoin (NIT) & 30 & $\mathrm{R}$ & $\mathrm{R}$ & $\mathrm{I}$ & $\mathrm{R}$ & $\mathrm{R}$ & $\mathrm{R}$ & $\mathrm{R}$ & $\mathrm{R}$ \\
\hline Penicillin & Amoxicillin (AMP) & 25 & $\mathrm{R}$ & $\mathrm{R}$ & $\mathrm{R}$ & $\mathrm{R}$ & $\mathrm{R}$ & $\mathrm{R}$ & $\mathrm{R}$ & $\mathrm{R}$ \\
\hline Polyketide & Tetracycline (TE) & 30 & $\mathrm{R}$ & $\mathrm{R}$ & $\mathrm{R}$ & $\mathrm{R}$ & I & $\mathrm{R}$ & $\mathrm{R}$ & I \\
\hline Quinolone & Nalidixic acid (NA) & 30 & $\mathrm{R}$ & $\mathrm{R}$ & $\mathrm{R}$ & $\mathrm{R}$ & $\mathrm{R}$ & $\mathrm{R}$ & $\mathrm{R}$ & $\mathrm{R}$ \\
\hline Sulfonamides & Sulfamethoxazole (SXT) & 25 & $\mathrm{R}$ & I & $\mathrm{R}$ & $\mathrm{R}$ & $\mathrm{R}$ & $\mathrm{R}$ & $\mathrm{R}$ & $\mathrm{R}$ \\
\hline \multicolumn{3}{|c|}{ Multiple antibiotics resistance (MAR) index } & 0.88 & 0.75 & 0.63 & 0.88 & 0.63 & 1.00 & 0.88 & 0.75 \\
\hline
\end{tabular}

$\mathrm{P}=$ Proteus mirabilis, $\mathrm{E}=$ Escherichia coli, $\mathrm{K}=$ Klebsiella pneumoniae. $\mathrm{R}=\mathrm{resistant}, \mathrm{S}=$ sensitive, $\mathrm{I}=$ intermediate according to CLSI (Clinical and Laboratory Standards Institute).

Antibacterial activity test of seaweed extracts

Results in Table 3 showed the antibacterial activity of different seaweed extracts using different $(80 \%)$ organic solvents (ethanol, methanol, acetone and water) to enable extraction of all possible active components from different seaweeds. All the extracts showed considerable activities depending on the bacterial isolate sensitivity. The ethanol extracts of Ulva lactuca showed broad significant antibacterial activity than the other used solvents recording 36, 34 and $39 \mathrm{~mm}$ diameter of inhibition zone for Escherichia coli E1, Klebsiella pneumoniae $\mathrm{K} 1$ and Proteus mirabilis $\mathrm{P} 1$, respectively at $P \leq 0.05$, followed by the extract of Gelidium spinosum and the extract of Petalonia fascia. In the same direction, methanol extracts of Ulva lactuca possessed the highest antibacterial activity than that of Gelidium spinosum and 
Petalonia fascia against E. coli E2 (29 mm), $K$. pneumoniae $\mathrm{K} 1(26 \mathrm{~mm})$ and $P$. mirabilis P2 $(25 \mathrm{~mm})$, respectively. The acetone and water extracts showed lower, yet significant, antibacterial activities compared to ethanol and methanol extracts. Seaweeds contain various bioactive substances which have many pharmaceutical applications. Some of these substances have bacteriostatic and bactericidal properties as reported by (Gorban et al., 2003; Ismail et al., 2016).

Ulva lactuca was reported to contain uniform distribution of antibiotics (Hornsey and Hide, 1974). (Fareed and Khairy, 2008) explained that Ulva lactuca possessed proteins or peptides responsible for the antibacterial activity, which function by binding to the microbial cell membrane and once embedded, forming pore-like membrane defects that allow efflux of essential ions and nutrients from the bacteria. The results of the present study were in accordance with (Manilal et al., 2009), who reported that moderate polar solvents like ethanol showed better activity against Gram negative bacteria, which are the main cause of UTI diseases.

The ethanol extracts of green algae like Codium adherens, Ulva reticulate and Halimeda macroloba showed high antibacterial activity against Staphylococcus sp., Propionibacterium acnes and Proteus mirabilis (Karthikaidevi et al., 2009; Boonchum et al., 2011). Similarly, ethanolic extract of Caulerpa sertularioides green seaweeds showed maximum antibacterial activity against Bacillus subtilis, E. coli and Proteus mirabilis (Pushparaj et al., 2014).

For Phaeophyceae (brown seaweeds), the ethanolic extract of Sargassum oligocystum and Sargassum crassifolium showed high antibacterial activity against E. coli (Francis et al., 2017). Earlier, (Padmakumar and Ayyakkannu, 1997) reported that Chlorophyceae are actively growing throughout the year, which ensure its continuous availability whereas Phaeophyceae show no active growth in certain seasons. Practically, the antibacterial activities of certain algal extract will be dependent on the tested algal species, the efficacy of the extraction method and the concentration of this extract.

In this respect, results in Figure 1 represented the means of antibacterial activities of different seaweed extracts using different solvents. Ethanol extracts of all seaweeds showed significantly high antibacterial activity compared to the other solvents. Fortunately, the ethanol extract of $U$. lactuca showed the maximum antibacterial activity with the isolates $\mathrm{E} 1, \mathrm{~K} 1$, and $\mathrm{P} 1$, which were estimated to have the highest MAR index values (Table 2). Therefore, the ethanol extract of Ulva lactuca was subjected to further chemical analysis to identify its chemical components.

\section{Identification of the selected bacterial isolates}

The obtained results in Table 4 using the Biomerieux VITEK®2 system confirmed the morphological and biochemical identification and showed that the three bacterial isolates are Escherichia coli, Klebsiella pneumoniae and Proteus mirabilis.

\section{Fractionation and purification of Ulva lactuca antibacterial crude extract}

\section{Column chromatography}

The crude ethanolic extract of Ulva lactuca seaweed was fractioned and purified using silica gel column chromatography. From fifteen fractions obtained, only five fractions showed antibacterial activity against the selected multidrug resistant UTI bacterial isolates (Escherichia coli, Klebsiella pneumoniae and Proteus mirabilis). 
The recorded inhibition zones for different fractions were illustrated in Table 5. All five fractions recorded remarkable inhibition zones against the three-tested resistant pathogenic isolates especially $\mathrm{Fr} 2, \mathrm{Fr} 3$ and Fr8.

\section{Determination of the chemical structure of Ulva lactuca antibacterial compound}

\section{UV spectrophotometer analysis}

The ultraviolet absorption of the most active antibacterial fractions, which collected from column chromatography was measured using UV spectrophotometer (UV $2101 / \mathrm{pc}$ ) at 200$900 \mathrm{~nm}$ wavelength. The absorption peaks of the five active fractions were of similar UV absorption at $245 \mathrm{~nm}$ (Fig. 2a, b, c, d and e) confirming its purity and homogeneity.

Consequently, the five fractions were collected together to form one active compound with the same estimated UV absorption peak at $245 \mathrm{~nm}$ (Fig. 2f) suggesting an aromatic acid esters structure of $U$. lactuca antibacterial bioactive agent.
Infra-red spectrophotometer analysis

The infra-red absorption spectrum was used to identify the functional groups frequencies of $U$. lactuca ethanolic extract, which constitute the active compound structures. A FT-IR spectrum was recorded in the range of 4000 to $400 \mathrm{~cm}^{-1}$ and the following functional groups were recorded (Fig. 3).

The strong stretching broad band (v) of $\mathrm{OH}$ group was positioned at $3450 \mathrm{~cm}^{-1}$. The $v$ of $\mathrm{CH}$ aliphatic $\left(\mathrm{CH}, \mathrm{CH}_{2}\right.$ and $\left.\mathrm{CH}_{3}\right)$ sharp band was at $2861.84 \mathrm{~cm}^{-1}$.

A sharp band of $\mathrm{C}=\mathrm{O}$ was positioned at $1730.8 \mathrm{~cm}^{-1}$. A strong sharp (v) of $\mathrm{C}=\mathrm{C}$ and $\mathrm{C}-\mathrm{O}$ were positioned at $1461.78 \mathrm{~cm}^{-1}$ and $1277.61 \mathrm{~cm}^{-1}$, respectively. In addition, a band (v) of ortho-position, aromatic phenyl ring $\left(\mathrm{CH}, \mathrm{CH}_{2}\right.$ and $\left.\mathrm{CH}_{3}\right)$ was at $785.85 \mathrm{~cm}^{-1}$.

There was no absorbance in between the region $2220-2260 \mathrm{~cm}^{-1}$ indicates that there was no cyanide group in -this extract. This result shows that $U$. lactuca extract does not contain toxic substances.

Fig.1 The mean antibacterial activities of different seaweed extracts against the multidrug resistant UTI bacterial isolates

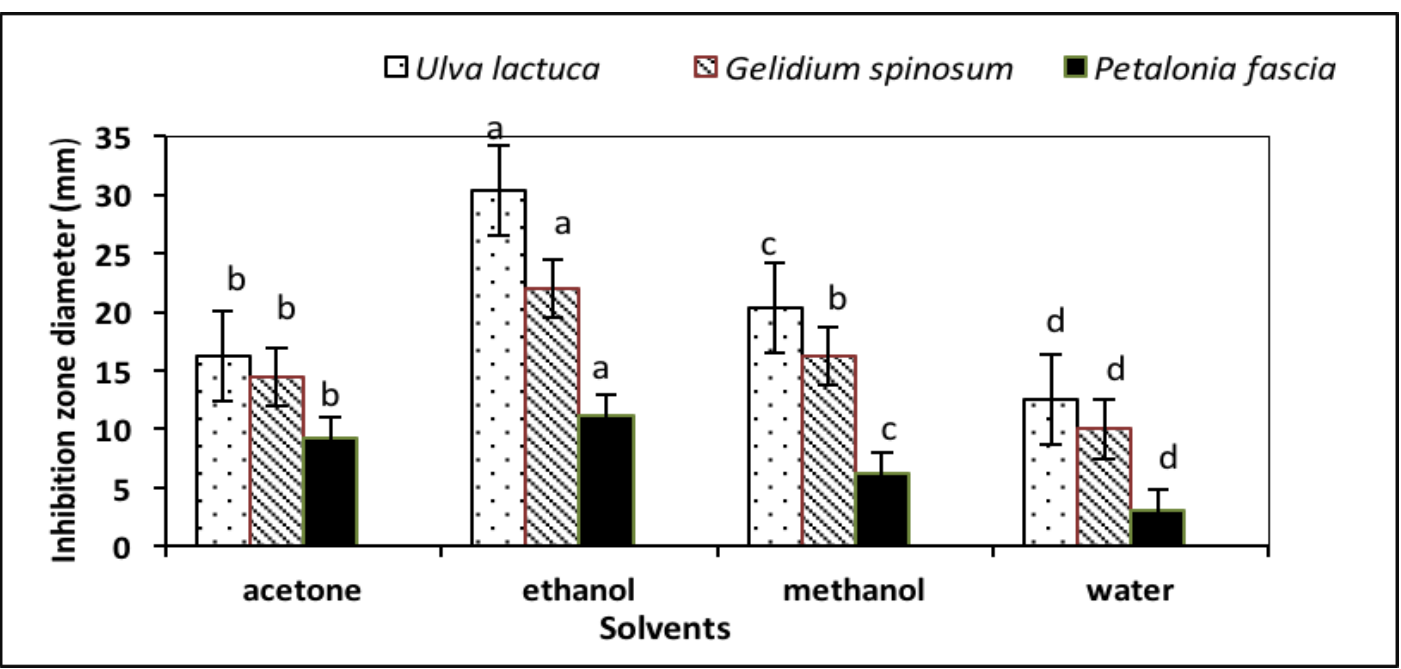


Fig.2 The UV spectrophotometer scanning of different active fractions resulted from column chromatography. $\mathrm{a}=$ fraction no. $2, \mathrm{~b}=$ fraction no. $3, \mathrm{c}=$ fraction no. $4, \mathrm{~d}=$ fraction no.5, $\mathrm{e}=$ fraction no. 8 and $\mathrm{f}=$ total fractions collected together
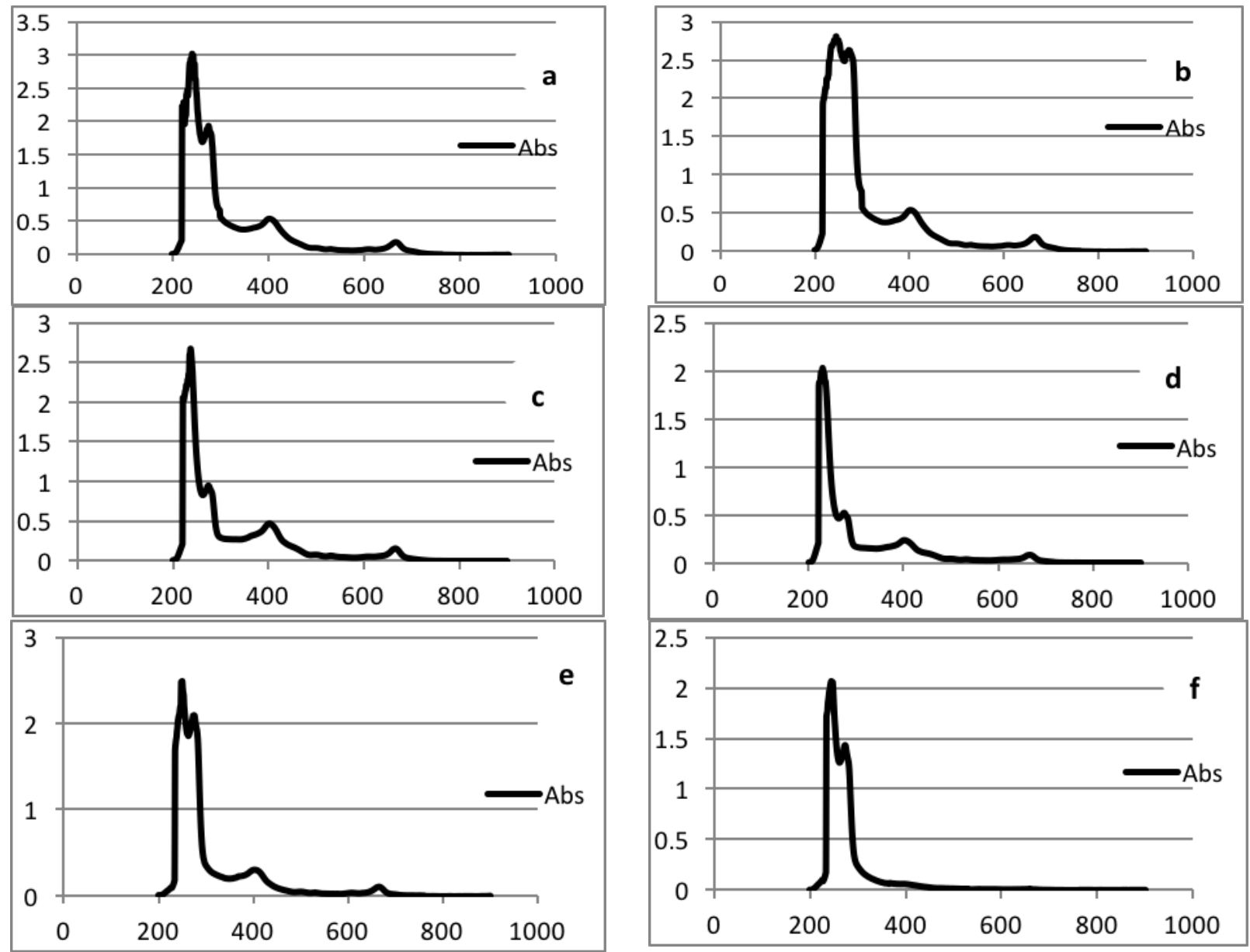

Fig.3 IR spectra of Ulva lactuca antibacterial bioactive compound

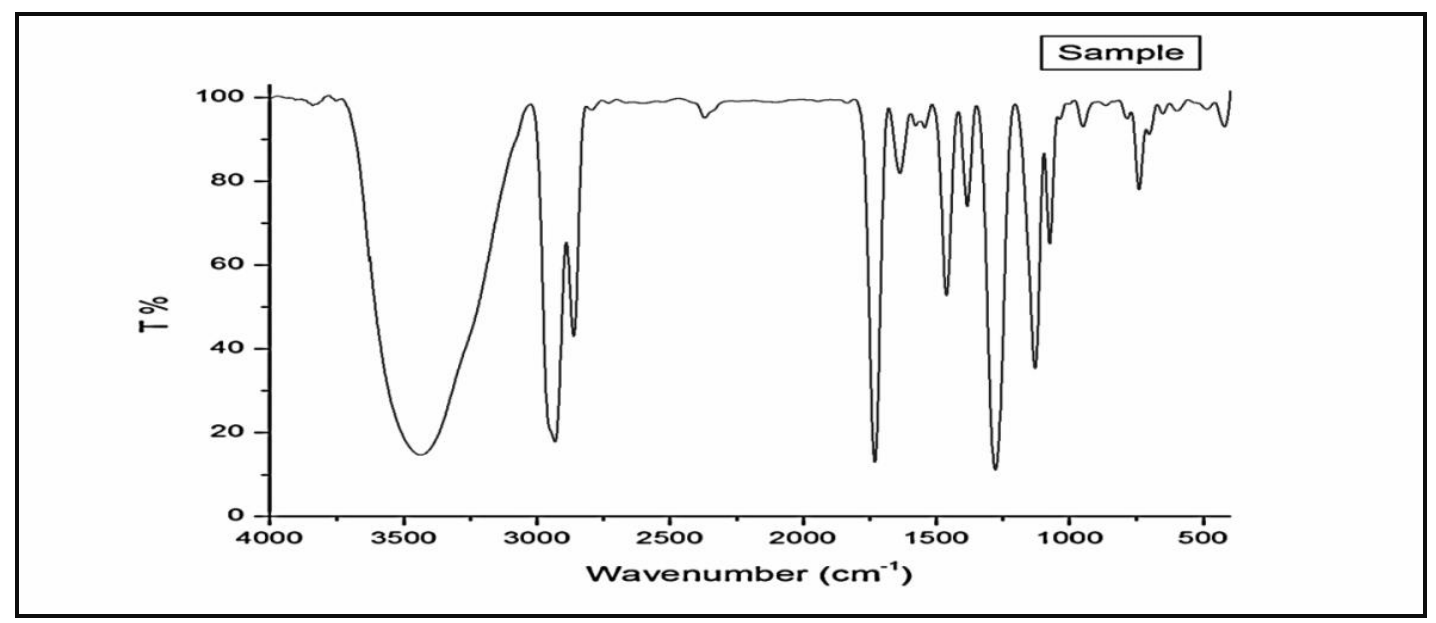


Fig.4 Proton magnetic resonance graph of $U$. lactuca antibacterial bioactive compound

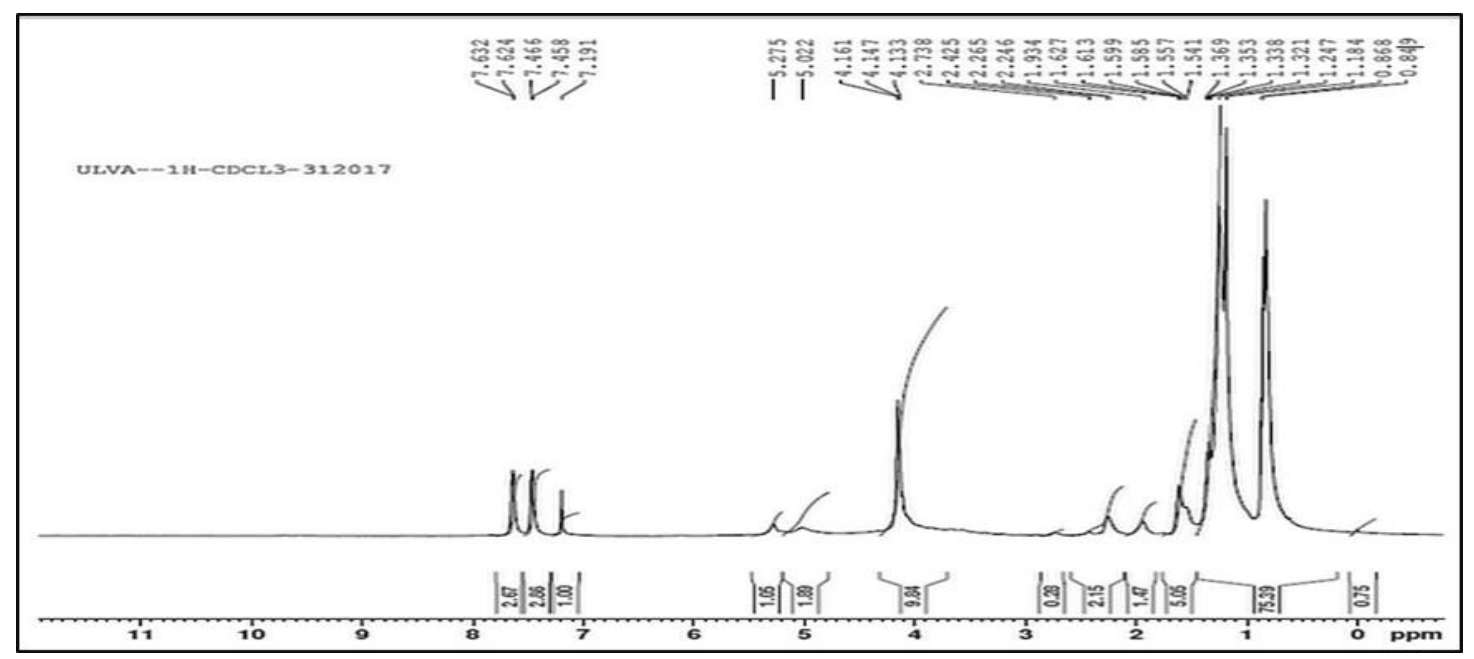

Fig.5 GC-MS analysis chromatogram of Ulva lactuca antibacterial bioactive compound

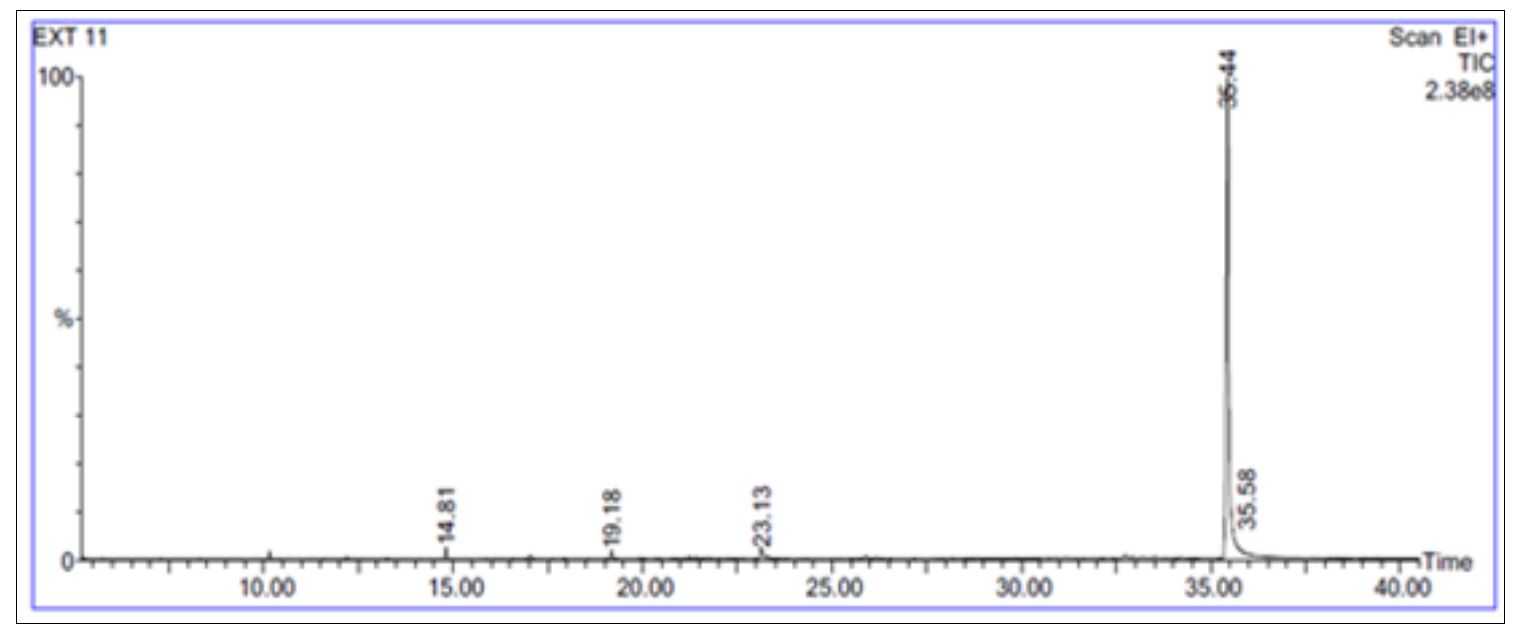

Fig.6 Chemical structure of di-isooctyl phthalate, the antibacterial bioactive compound from Ulva lactuca ethanolic extract

\begin{tabular}{|l|} 
Chemical structure \\
Chemical name \\
Molecular formula \\
Molecular weight \\
Density
\end{tabular}


Table.3 The antibacterial activity of different seaweed extracts against the selected multidrug resistant UTI bacterial isolates

\begin{tabular}{|c|c|c|c|c|c|c|c|c|c|c|}
\hline \multirow{3}{*}{ Solvents } & \multirow{2}{*}{ Bacterial isolate } & \multicolumn{3}{|c|}{ E. coli } & \multicolumn{2}{|c|}{ K. pneumonia } & \multicolumn{4}{|c|}{ P. mirabilis } \\
\hline & & E 1 & E2 & E3 & K1 & $\mathrm{K} 2$ & P1 & P2 & P3 & P4 \\
\hline & Seaweeds & & & & Diameter & ff inhibition & one (mm) & & & \\
\hline Acetone & $\begin{array}{l}\text { Gelidium } \\
\text { spinosum } \\
\text { Petalonia fascia } \\
\text { Ulva lactuca }\end{array}$ & $\begin{array}{c}7^{\mathrm{d}} \pm 0.15 \\
11^{\mathrm{bc}} \pm 1.6 \\
18^{\mathrm{bc}} \pm 0.1\end{array}$ & $\begin{array}{l}6^{\mathrm{d}} \pm 0.3 \\
10^{\mathrm{bc}} \pm 1.5 \\
17^{\mathrm{bc}} \pm 0.1\end{array}$ & $\begin{array}{l}3^{\mathrm{e}} \pm 0.5 \\
13^{\mathrm{b}} \pm 0.9 \\
14^{\mathrm{c}} \pm 0.3\end{array}$ & $\begin{array}{c}10^{\mathrm{c}} \pm 2.6 \\
0 \pm 00 \\
20^{\mathrm{b}} \pm 0.7\end{array}$ & $\begin{array}{c}19^{\mathrm{a}} \pm 2.5 \\
0 \pm 00 \\
15^{\mathrm{c}} \pm 0.2\end{array}$ & $\begin{array}{c}10^{\mathrm{c}} \pm 3.2 \\
13^{\mathrm{b}} \pm 0.03 \\
7^{\mathrm{d}} \pm 0.06\end{array}$ & $\begin{array}{c}0 \pm 00 \\
12^{\mathrm{b}} \pm 2.6 \\
9.5^{\mathrm{d}} \pm 0.05\end{array}$ & $\begin{array}{c}18^{\mathrm{a}} \pm 0.00 \\
8^{\mathrm{c}} \pm 1.3 \\
26^{\mathrm{a}} \pm 0.03\end{array}$ & $\begin{array}{l}15^{\mathrm{b}} \pm 0.6 \\
17^{\mathrm{a}} \pm 2.0 \\
20^{\mathrm{b}} \pm 0.6\end{array}$ \\
\hline Ethanol & $\begin{array}{l}\text { Gelidium } \\
\text { spinosum } \\
\text { Petalonia fascia } \\
\text { Ulva lactuca }\end{array}$ & $\begin{array}{l}20^{\mathrm{c}} \pm 0.5 \\
13 \pm 0.2 \\
36^{\mathrm{ab}} \pm 0.03\end{array}$ & $\begin{array}{l}18^{c} \pm 0.1 \\
11^{b} \pm 1.7 \\
18^{c} \pm 0.3\end{array}$ & $\begin{array}{l}29^{\mathrm{a}} \pm 0.3 \\
14^{\mathrm{a}} \pm 0.1 \\
30^{\mathrm{b}} \pm 0.5\end{array}$ & $\begin{array}{l}16^{\mathrm{d}} \pm 0.4 \\
8^{\mathrm{b}} \pm 2.6 \\
34^{\mathrm{ab}} \pm 0.3\end{array}$ & $\begin{array}{l}23^{\mathrm{bc}} \pm 0.7 \\
13^{\mathrm{a}} \pm 1.00 \\
27^{\mathrm{b}} \pm 0.01\end{array}$ & $\begin{array}{l}22^{\mathrm{bc}} \pm 0.3 \\
8^{\mathrm{b}} \pm 3.0 \\
39^{\mathrm{a}} \pm 0.01\end{array}$ & $\begin{array}{l}18^{\mathrm{c}} \pm 0.05 \\
10^{\mathrm{b}} \pm 0.3 \\
32^{\mathrm{ab}} \pm 0.03\end{array}$ & $\begin{array}{l}24^{\mathrm{b}} \pm 0.03 \\
10^{\mathrm{b}} \pm 0.3 \\
29^{\mathrm{b}} \pm 0.02\end{array}$ & $\begin{array}{l}26^{\mathrm{b}} \pm 0.6 \\
13^{\mathrm{a}} \pm 0.5 \\
28^{\mathrm{b}} \pm 0.17\end{array}$ \\
\hline Methanol & $\begin{array}{l}\text { Gelidium } \\
\text { spinosum } \\
\text { Petalonia fascia } \\
\text { Ulva lactuca }\end{array}$ & $\begin{array}{l}20^{\mathrm{a}} \pm 0.05 \\
6^{\mathrm{b}} \pm 0.4 \\
13^{\mathrm{d}} \pm 0.06\end{array}$ & $\begin{array}{l}13^{\mathrm{d}} \pm 0.01 \\
8^{\mathrm{d}} \pm 0.5 \\
29^{\mathrm{a}} \pm 0.02\end{array}$ & $\begin{array}{l}15^{\mathrm{c}} \pm 0.01 \\
10^{\mathrm{a}} \pm 0.2 \\
15^{\mathrm{cd}} \pm 0.05\end{array}$ & $\begin{array}{l}12^{\mathrm{d}} \pm 0.7 \\
8^{\mathrm{d}} \pm 0.06 \\
26^{\mathrm{b}} \pm 0.1\end{array}$ & $\begin{array}{l}17^{\mathrm{a}} \pm 0.19 \\
0 \pm 00 \\
17^{\mathrm{c}} \pm 0.03\end{array}$ & $\begin{array}{l}19^{\mathrm{a}} \pm 0.5 \\
9^{\mathrm{a}} \pm 0.6 \\
23^{\mathrm{bc}} \pm 0.0 \\
1\end{array}$ & $\begin{array}{l}15^{\mathrm{c}} \pm 0.3 \\
7^{\mathrm{ab}} \pm 0.04 \\
25^{\mathrm{b}} \pm 0.02\end{array}$ & $\begin{array}{l}18^{\mathrm{ab}} \pm 0.7 \\
5^{\mathrm{b}} \pm 0.6 \\
18^{\mathrm{c}} \pm 0.05\end{array}$ & $\begin{array}{l}17^{\mathrm{ab}} \pm 0.17 \\
3^{\mathrm{c}} \pm 0.05 \\
17^{\mathrm{c}} \pm 0.07\end{array}$ \\
\hline Water & $\begin{array}{l}\text { Gelidium } \\
\text { spinosum } \\
\text { Petalonia fascia } \\
\text { Ulva lactuca }\end{array}$ & $\begin{array}{l}6^{c} \pm 0.03 \\
0 \pm 00 \\
11^{c} \pm 0.02\end{array}$ & $\begin{array}{l}12^{\mathrm{ab}} \pm 0.5 \\
0 \pm 00 \\
12^{\mathrm{bc}} \pm 0.7\end{array}$ & $\begin{array}{l}14^{\mathrm{a}} \pm 0.3 \\
11^{\mathrm{a}} \pm 1.3 \\
13^{\mathrm{b}} \pm 0.3\end{array}$ & $\begin{array}{l}12^{\mathrm{ab}} \pm 0.7 \\
0 \pm 00 \\
21^{\mathrm{a}} \pm 0.5\end{array}$ & $\begin{array}{l}10^{b} \pm 0.1 \\
2^{c} \pm 1.02 \\
11^{c} \pm 0.1\end{array}$ & $\begin{array}{l}7^{c} \pm 0.5 \\
5^{c} \pm 0.02 \\
13^{b} \pm 0.03\end{array}$ & $\begin{array}{l}11^{\mathrm{b}} \pm 0.3 \\
2^{\mathrm{c}} \pm 1.02 \\
11^{\mathrm{c}} \pm 0.05\end{array}$ & $\begin{array}{l}5^{c} \pm 0.2 \\
8^{b} \pm 0.02 \\
10^{c} \pm 0.03\end{array}$ & $\begin{array}{l}13^{\mathrm{a}} \pm 0.02 \\
0 \pm 00 \\
14^{\mathrm{b}} \pm 0.04\end{array}$ \\
\hline
\end{tabular}

Different letters in the same row indicat significant difference at $\mathrm{P} \leq 0.05$.

Table.4 VITEK identification of the isolated multi-drug UTI bacterial isolates

\begin{tabular}{lcccc}
\hline \multicolumn{1}{c}{ Tested organism } & Bio-number & Card & Confidence & Probability \% \\
\hline Escherichia coli & 0405610540526610 & GN (Gram negative) & Excellent identification & 97 \\
Klebsiella pneumoniae & 6627734773565010 & GN (Gram negative) & Excellent identification & 97 \\
Proteus mirabilis & 0017000340642210 & GN (Gram negative) & Excellent identification & 99 \\
\hline
\end{tabular}


Table.5 The antimicrobial activities of the different fractions obtained from the silica gel column chromatography against seaweeds sensitive bacterial isolates

\begin{tabular}{lclccc}
\hline \multicolumn{1}{c}{ Fractions } & Fr2 & Fr3 & Fr4 & Fr5 & Fr8 \\
\hline Bacterial isolates & & \multicolumn{2}{c}{ Diameter of } & inhibition \\
\hline E. coli & 10 & 18 & 11 & 10 & 13 \\
K. pneumoniae & 13 & 17 & 9 & 7 & 14 \\
P. mirabilis & 12 & 19 & 10 & 8 & 15 \\
\hline
\end{tabular}

Table.6 GC-MS analysis of Ulva lactuca antibacterial bioactive compound

\begin{tabular}{cccccc}
\hline Peak & $\begin{array}{c}\text { Retention } \\
\text { Time }(\min )\end{array}$ & Height & Area & $\begin{array}{c}\text { Relative peak } \\
\text { intensity \% }\end{array}$ & Compound name \\
\hline $\mathbf{1}$ & 14.812 & $6,261,656$ & $235,828.4$ & 1.13 & Hexadecane \\
$\mathbf{2}$ & 19.179 & $4,590,217$ & $187,301.5$ & 0.9 & Sulfurous acid 2 ethylisohexyl ester \\
$\mathbf{3}$ & 23.131 & $5,819,614$ & $337,434.7$ & 1.62 & Hexadecanoic acid ethyl ester \\
$\mathbf{4}$ & 35.436 & $237,067,360$ & $20,885,660$ & 100 & Diisooctylphthalate \\
\hline
\end{tabular}

Table.7 Number and size of PCR amplification products of UTI bacterial isolates virulence genes that was sensitive to Ulva lactuca extract

\begin{tabular}{|c|c|c|c|c|c|c|c|c|c|c|c|c|}
\hline $\begin{array}{c}\text { Bacterial } \\
\text { isolates }\end{array}$ & \multicolumn{3}{|c|}{ Escherichia coli } & \multicolumn{3}{|c|}{ Klebsiella pneumoniae } & \multicolumn{3}{|c|}{ Proteus mirabilis } & \multicolumn{3}{|c|}{$\begin{array}{c}\text { Proteus mirabilis } \\
\text { (+ve control) }\end{array}$} \\
\hline $\begin{array}{l}\text { Virulence } \\
\text { gene }\end{array}$ & $\begin{array}{l}\overline{0} \\
.0 \\
0 \\
0 \\
\overline{0} \\
\end{array}$ & 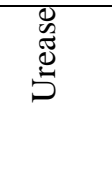 & 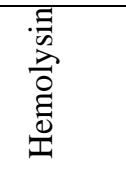 & 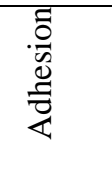 & 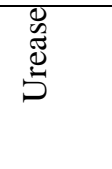 & 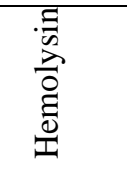 & $\begin{array}{l}\overline{0} \\
.0 \\
0 \\
0 \\
\frac{0}{0} \\
\end{array}$ & 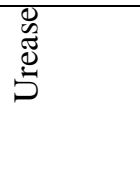 & 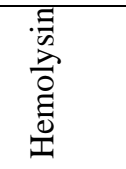 & $\begin{array}{l}.5 \\
0 \\
0 \\
\frac{0}{8} \\
\&\end{array}$ & 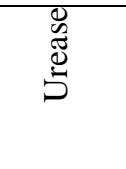 & 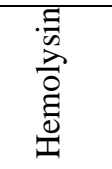 \\
\hline Primer pair & 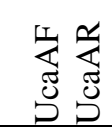 & 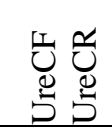 & 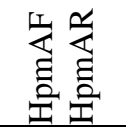 & 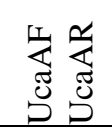 & 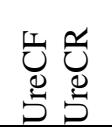 & 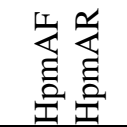 & 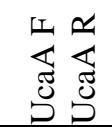 & 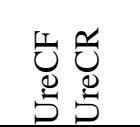 & 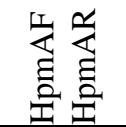 & 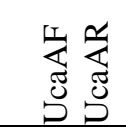 & 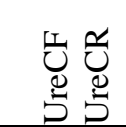 & 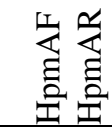 \\
\hline $\begin{array}{l}\text { No. of } \\
\text { amplified } \\
\text { PCR } \\
\text { products }\end{array}$ & 1 & 2 & 2 & 1 & 2 & 2 & 1 & 2 & 1 & 2 & 2 & 2 \\
\hline $\begin{array}{l}\text { Size of the } \\
\text { PCR } \\
\text { products }\end{array}$ & $750 \mathrm{bp}$ & $\begin{array}{l}750 \mathrm{bp} \\
250 \mathrm{bp}\end{array}$ & $\begin{array}{l}\text { 375bp } \\
\text { 875bp }\end{array}$ & $750 \mathrm{bp}$ & $\begin{array}{l}750 \mathrm{bp} \\
625 \mathrm{bp}\end{array}$ & $\begin{array}{l}\text { 375bp } \\
1050 b p\end{array}$ & $780 \mathrm{bp}$ & $\begin{array}{l}\text { 650bp } \\
1050 \mathrm{bp}\end{array}$ & 375 bp & $\begin{array}{l}750 \mathrm{bp} \\
125 \mathrm{bp}\end{array}$ & $\begin{array}{l}750 \mathrm{bp} \\
250 \mathrm{bp}\end{array}$ & $\begin{array}{l}\text { 375bp } \\
\text { 875bp }\end{array}$ \\
\hline
\end{tabular}


Fig.7 Agarose gel of PCR amplification products of UTI bacterial isolates virulence genes that was sensitive to Ulva lactuca extract.

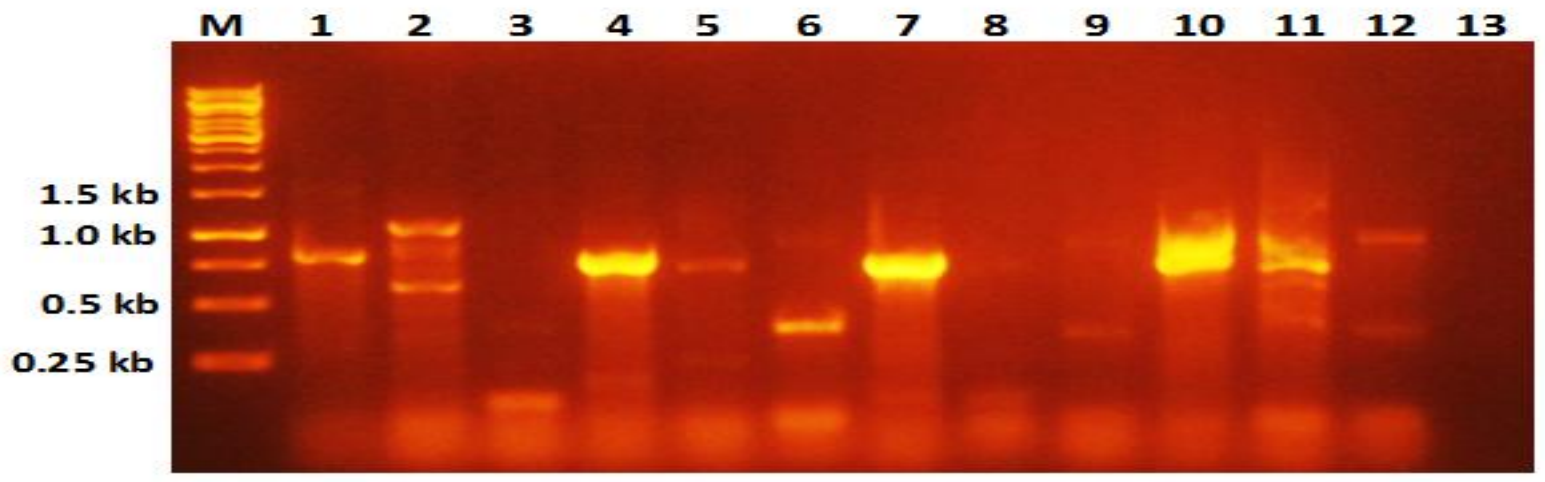

Lane M: O'-Gene Ruler $1 \mathrm{~kb}$ DNA ladder as the molecular size marker. Lanes 1, 2 and 3: adhesion, urease and hemolysin genes detected in Proteus mirabilis. Lanes 4, 5 and 6: adhesion, urease and hemolysin genes detected in Proteus mirabilis (positive control strain). Lanes: 7, 8 and 9: adhesion, urease and hemolysin genes detected in Escherichia coli. Lanes 10, 11 and 12: adhesion, urease and hemolysin genes detected in Klebsiella pneumoniae. Lane 13 water: negative control (no DNA template was used).

\section{Proton nuclear magnetic resonance} ( ${ }^{1}$ HNMR) analysis

Figure 4 showed the $\left({ }^{1} \mathrm{H}\right.$ NMR) spectral analysis graph of Ulva lactuca antibacterial bioactive compound for accurate elucidation of its chemical structure. The characteristic signals of the compound in ${ }^{1} \mathrm{H}$ NMR spectrum were as following: The signal from 1.784$1.321 \mathrm{ppm}$ was singlet (12 protons) of $4 \mathrm{CH}_{3}$ groups. The signal from 1.541-1.621 ppm was singlet (16 protons) of $8 \mathrm{CH}_{2}$ groups. The signal from 2.246-2.738 ppm was singlet (2 protons) of $2 \mathrm{CH}$ groups. The signal from 5.022-5.275 was singlet (4 protons) of $2 \mathrm{H}_{2} \mathrm{C}$ O- groups. And the signal from 7.191-7.632 was multiple (4 protons) of aromatic groups.

\section{Gas chromatography mass spectrometry GC-MS analysis}

The GC-MS chromatogram of $U$. lactuca ethanolic antibacterial active compound indicated the presence of 4 peaks with different retention times and peak relative intensities as shown in Table 6 and Figure 5 and 6. All peak areas of the chromatogram were relatively small except the parent peak at retention time of $35.436 \mathrm{~min}$, corresponds to $100 \%$ relative intensity and was identified according to its molecular mass to be diisooctyl phthalate, an aromatic ester derivative compound.

Phthalate esters have been found earlier in aquatic organisms and can be potentially bioaccumulated due to their lipophilicity (Mackintosh et al., 2004). Phenolic compounds are commonly found in seaweeds and have been reported to have several biological activities including antimicrobial and antioxidant activities (Yuan et al., 2005). Many studies have reported the production of phthalate esters by seaweeds. Diisooctyl phthalate was isolated from the brown algae Sargassum wightii and showed antibacterial activity against Gram positive and Gram negative bacteria Staphylococcus aureus, Proteus vulgaris, E. coli, Salmonella typhi, S. paratyphi, S. typhiridium and Pseudomonas aeruginosa (Sastry and Rao, 1995).

The biosynthesis of di-(2-ethylhexyl)phthalate (DEHP) and di-n-butyl phthalate 
(DBP) have been reported by (Chen, 2004) in the red alga Bangia atropurpurea. According to Osman et al., (2013), a high molecular weight phthalate esters derivative of broad spectrum antibacterial and antifungal activities was synthesized by Ulva fasciata green seaweed. The extract of Grateloupa lithophila seaweed was recommended as antibacterial substance for multidrug resistant (MDR) microbes including the UTI bacteria (Manikandan et al., 2011). Some marine brown algae were screened by Kalaivani et al., (2016) and were reported to produce antagonistic bioactive compounds against UTI pathogens.

\section{Molecular detection of the virulence factors of the bacterial strains}

\section{PCR amplification of virulence factors}

Three different primer pairs (UcaAF UcaAR; UreCF UreCR; HpmAF HpmAR) were used to detect the virulence genes (adhesion, hemolysin and urease) of the tested multidrug resistant UTI bacterial isolates (E. coli, $K$. pneumoniae and $P$. mirabilis). Various virulence factors can be attributed to UTI pathogenicity (Tarchouna et al., 2013). The Polymerase Chain Reaction technique was used to investigate the virulence genes responsible for multidrug resistance in the UTI bacterial isolates. Specific primers for three virulence genes in the bacterial isolates including ucaA (adhesion), ureC (urease), and hpmA (hemolysin) were selected. These three genes are responsible for the colonization of bacteria in the urinary tract.

The seaweeds sensitive UTI bacterial isolates were compared with the antibiotics and seaweed resistant isolate (positive control) carrying the virulence genes. The current results (Table 7 and Fig. 7) showed that the adhesion virulence gene was detected in all the bacterial isolates (E. coli, K. pneumoniae and $P$. mirabilis) with rate of $95 \%$ with one amplicon (780 bp) for Proteus mirabilis and $750 \mathrm{bp}$ for both of E. coli and Klebsiella pneumoniae, while in the positive control strain 2 PCR amplicons (750bp and faint $125 \mathrm{bp}$ ) were observed, which indicated that the resistant strain (positive control) utilize a variety of adhesions to bind to the urinary epithelial cells to start the infection causing failure to the treatment with antibiotics and seaweeds (Le Bouguenec et al., 1992; Munkhdelger et al., 2017).

Regarding the ureC gene, which is considered as a diagnostic feature of presence of UTI bacteria due to the production of urease enzyme; the results showed that all the isolates in a rate $96.66 \%$ contained ureC gene. Two PCR products (750bp and 625bp) were observed in Klebsiella pneumoniae and in Proteus mirabilis (650bp and 1050bp), while two faint amplicons (750bp and 250bp) were amplified in E. coli. Similarly, in the positive (control) isolate the 2 faint PCR amplicons (750bp and 250bp) were amplified (Table 7 and Fig. 7). Urease enzyme works on changing $\mathrm{pH}$ of the urine to basic leading to the deposition of calcium and magnesium phosphate salts in the formed biofilm, which in turn leads to the formation of more complex crystalline biofilm that works to close urinary catheter and protect the bacteria from antibiotics (Stickler, 2008; Schaffera et al., 2016).

HpmA gene is responsible for producing hemolycin and considered as an important virulence factor for UTI bacterial pathogenicity. The hpmA gene was detected in all bacterial isolates. In Proteus mirabilis, only very faint amplicon (375bp) was detected in this strain. Two PCR amplicons (375bp and 875bp) of hpmA gene were present in E. coli and in the positive control. Similarly, two faint PCR products (375bp and $1050 \mathrm{bp})$ were observed in case of $K$. 
pneumoniae. The hemolysin enzyme acts on destroying the leukocyte cells by making small holes in the membranes of leukocyte and epithelial cells. Its presence is a very important factor in providing the pathogenic bacteria with iron; and because of its cytotoxic, it leads to the destruction of the kidney tissue of the host (Cestari et al., 2013; Leclercq et al., 2016).

By linking the obtained results from antibacterial activities of $U$. lactuca extract with that of the PCR of the studied UTI bacterial isolates, it revealed that presence of the virulence genes (adhesion, urease and hemolysin) is a crucial factor for successful colonization of the uropathogenic bacteria and its multidrug resistance property. Seaweed derived compounds proved their ability as new natural sources for antibacterial agents, which reduce the virulence genes activity and prevent (as for $P$. mirabilis) or mitigate (as for $E$. coli and $K$. pneumoniae) the resistance and pathogenicity of these kind of bacteria.

Marine algae are one of the biggest biomass producers and proved a potential source of new and unique compounds for many applications. Many compounds derived from seaweed have bacteriostatic or antibacterial, antiviral, antitumor, anti-inflammatory and antifouling activities. In this study, an aromatic ester derivative was extracted from Ulva lactuca green seaweed using ethanol. The bioactive compound was chemically identified as diisooctyl phthalate and showed promising antibacterial activities against multidrug resistant UTI infectious bacteria. In addition, the virulence genes causing pathogenicity of these bacteria were detected using PCR. PCR results showed that hemolysin, urease and adhesion virulence factors were present in the treated $P$. mirabilis, E. coli and $K$. pneumoniae UTI isolates with high variations. Consequently, the study recommends seaweeds as promising treatment of human diseases or as new antibacterial agents to replace synthetic antibacterial drugs.

\section{References}

Adaikalaraj, G., Patric Raja, D., Johnson, M., Janakiraman, N., Babu, A., 2012. Antibacterial potential of selected Red seaweeds from Manapad coastal areas, Thoothukudi, TamilNadu, India. Asian Pacific Journal of Tropical Medicine 1077-1080.

Aleem, A.A., 1993. The Marine Algae of Alexandria Egyptian Books House faculty of science Alexandria. Egypt

Anderson, G., Martin, S., Hultgren, S., 2004. Host subversion by formation of intracellular bacterial communities in the urinary tract. Microbes and Infection 6, 1094-1101.

Atalah, E., Hernández Cruz, C.M., Izquierdo, M.S., Rosenlund, G., Caballero, M.J., Valencia, A., Robaina, L., 2007. Two microalgae Crypthecodinium cohnii and Phaeodactylum tricornutum as alternative source of essential fatty acids in starter feeds for Sea bream. Sparus aurata Aquaculture 270, 178-185.

Blunt, B.R., Copp, W.P., Hu, M.H.G., Munro, P.T., Northcote, M.R., 2007. UV-VIS and HPLC studies on marine natural product. Natural Product Reports 4, 3186.

Boeriu, C., Bravo, D., Gosselink, R., Gosselinkvan Dam, J., 2004. Characterisation of structure dependent functional properties of lignin with infrared spectroscopy. Industrial Crops and Products 20, 205-218.

Boonchum, W., Peerapornpisal, Y., Kanjanapothi, D., Pakkoh, J., Amornlerdpison, D., Pumas, C., Sangpaiboon, P., Vacharapiyasophon, P., 2011. Antimicrobial and antiinflammatory properties of various seaweeds from the Gulf of Thailand. 
International Journal of Agricultural and Biology 13, 100-104.

Cardoso, M.S., Carvalho, G.L., Silva, J.P., Rodrigues, S.M., Pereira, R.O., Pereira, L., 2014. Bioproducts from seaweeds: A review with special focus on the Iberian Peninsula. Current Organic Chemistry 18, 896-917.

Cestari, S.E., Ludovico, M.S., Martins, F.H., Da Rocha, W.P., Elisa, W.P., Pelayo, J.S., 2013. Molecular detection of HpmA and hlyA hemolysin of uropathogenic Proteus mirablis. Journal Microbial 67, 703-707.

Chen, C., 2004. Biosynthesis of di-(2ethylhexyl) phthalate (DEHP) and di-nbutyl phthalate (DBP) from Red alga Bangia atropurpurea. Water Research 38, 1014-1018.

Cheung, R.C.F., Wong, J.H., Pan, W., Chan, Y.S., Yin, C., Dan, X., Ng, T.B., 2015. Marine lectins and their medicinal applications. Applied Microbiology and Biotechnology 99, 3755-3773.

CLSI, 2012. Performance standards for antimicrobial disk susceptibility tests; approved standard $11^{\text {th }}$ ed CLSI document. Clinical and Laboratory Standards Institute, Wayne, PA.

Collee, J., Fraser, G., Marmion, P., Simmons, A., 1996. Practical Medical Microbiology. $\quad 4^{\text {th }}$ ed $\quad$ Churchill Livingstone, New York,pp. 413-418.

Dethlefsen, L., Huse, S., Sogin, M., Relman, D., 2008. The pervasive effects of an antibiotic on the human gut microbiota, as revealed by deep $16 \mathrm{~S}$ rRNA sequencing. PLOS Biology, 6:280.

Ejrnaes, K., 2011. Bacterial characteristics of importance for recurrent urinary tract infections caused by Escherichia coli. Danish Medical Bulletin 58, B4187.

El-Sheekh, M.M., El Shafay, S.M., Ali, S.S., 2016. Antimicrobial activity of some seaweeds species from Red sea, against multidrug resistant bacteria. Egyptian Journal of Aquatic Research. 42, 65-74.

Fareed, M., Khairy, H., 2008. In vitro antimicrobial activities of seaweeds collected from Abu-Qir Bay Alexandria
Egypt. World Applied Sciences Journal 5, 389-396.

Farshad, S., Ranjbar, R., Japoni, A., Hosseini, M., Anvarinejad, M., Mohammadzadegan, R., 2012. Microbial susceptibility, virulence factors and plasmid profiles of uropathogenic bacteria strains isolated from children in Jahrom, Iran. Archives of Iranian Medicine 15, 312-316.

Foxman, B., Brown, P., 2003. Epidemiology of urinary tract infections: transmission and risk factors, incidence, and costs. Infectious Disease Clinics of North America 41, 17-227.

Francis, N.B., Jonathan, M.B., Oliva, C.R., Amaro, N.a., Jayson, D.C., 2017. Phytochemicals screening and antimicrobial properties of Sargassum oligocystum and Sargassum crassifolium Extracts. Journal of medicinal plants studies 5, 382-387.

Gilbert, P., 1987. Inocula for Antimicrobial Sensitivity Testing: a Critical Review. Journal of Antimicrobial Chemotherapy 20, 147-154.

Gonzalez, C.M., Schaeffer, A.J., 1999. Treatment of urinary tract infection." What's old, what's new and what works. World Journal of Urology 6, 372-382.

Gorban, E., Kuprash, L., Gorban, N., 2003. Spirulina: perspectives of the application in medicine. Lik Sprava 7, 100-110.

Guiry, M., Guiry, G., 2016. AlgaeBase. Worldwide electronic publication, National University of Ireland http://www.algaebase.org.

Hacker, J.G., Oehler, B., Muhldorfer, I., Tschape, H., 1997. Pathogenicity islands of virulent bacteria: structure, function and impact on microbial evolution. Molecular Microbiology 23, 1089-1097.

Hornsey, I.S., Hide, D., 1974. The Production of antimicrobial compounds by British marine algae. I. Antibiotic-Producing marine algae. British Phycological Society Journal of Environmental Biology $9,353-361$. 
Ismail, M.M., Gheda, S.F., Pereira, L., 2016. Variation in bioactive compounds in some seaweeds from Abo Qir bay, Alexandria, Egypt. Rendiconti Fis. Acc. Lincei 27, 269-279.

Johnson, J., 1991. Virulence factors in Escherichia coli urinary tract infection. Clinical Microbiology Reviews 4, 80-118.

Kalaivani, G., Hemalatha, N., Poongothai, E., 2016. Screening of marine brown algae associated potential bacteria producing antagonistic bioactive compounds against UTI pathogens. International Journal of Pharma and Bio Sciences 7, 395-405.

Karthikaidevi, G., Manivannan, G., Thirumaran, G., Anantharaman, P., Balasubaramanian, $\quad$ T., 2009. Antibacterial Properties of Selected Green Seaweeds from Vedalai Coastal Waters; Gulf of Mannar Marine Biosphere Reserve. Global Journal of Pharmacology 3, 107-112.

Khelil-Radji, F., Belhouari, M.Y., ChemlalKherraz, D., Matallah-Boutiba, A., Boutiba, Z., 2017. Antimicrobial activity of aqueous and ethanol extracts of twomarine algae collected from Algerian west coast. International Journal of Biosciences 10, 100-104.

Khotimchenko, S.V., Vaskovsky, V.E., Titlyanavo, T.V., 2002. Fatty acids of marine algae from the Pacific coast of North California. Botanica Marina 45, 17-22.

Le Bouguenec, N.C., Archambaud, M., Labigne, A., 1992. Rapid and specific detection of the pap, afa, and sfa adhesins - encoding operons in uropathogenic Escherichia coli strains by Polymerase Chain Reaction. Journal of Clinical Microbiology 30, 1189-1193.

Leclercq, S.Y., Sullivan, M.J., Ipe, D.S., Smith, J.P., Cripps, A.W., Uletta, G.C., 2016. Pathogenesis of Streptococcus urinary tract infection depends on bacterial strain and $\beta$-hemolysin/cytolysin that mediates cytotoxicity cytokine synthesis inflammation and virulence. Scientific Reports 6:29000.
Mackintosh, C., Maldonado, J., Hongwu, J., Hoover, N., Chong, A., Ikonomou, M., Gobas, F., 2004. Distribution of phthalate esters in a marine aquatic food web: comparison to polychlorinated biphenyls. Environmental Science and Technology 38, 2011-2020.

Magiorakos, A., Srinivasan, A., Carey, R., 2012. Multidrug-resistant, extensively drug-resistant and pandrug-resistant bacteria: an international expert proposal for interim standard definitions for acquired resistance. Clinical Microbiology and Infection 18, 268-281.

Manikandan, S., Ganesapandian, S., Singh, M., Kumaraguru, A.K., 2011. Antimicrobial susceptibility pattern of urinary tract infection causing human pathogenic bacteria. Asian Journal of Medical Sciences 3, 56-60.

Manilal, A., Sujith, S., Selvin, J., Kiran, G.S., Shakir, C., Gandhimathi, R., Panikkar, M.V.N., 2009. Biopotentials Of Seaweeds Collected From Southwest Coast Of India. Journal of Marine Science and Technology 17, 67-73.

Munkhdelger, Y., Gunregjav, N., Dorjpurev, A., Juniichiro, N., Sarantuya, J., 2017. Detection of virulence genes, phylogenetic group and antibiotic resistance of uropathogenic Escherichia coli in Mongolia. Journal of infection in developing countries 11, 51-57.

Newman, D.J., Cragg, G.M., Snader, K.M., 2003. Natural products as source of new drugs over the period 1981-2002. Journal of Natural Product 66, 1022-1037.

Olayinka, A., Olayinka, B., Onile, B., 2009. Antibiotic susceptibility and plasmid pattern of Pseudomonas aeruginosa from the surgical unit of a University teaching hospital in North Central Nigeria. International Journal of Medical Science 1, 79-83.

Oliveira, F., Paludo, K., Arend, L., Farah, S., Pedrosa, F., Souza, E., 2011. Virulence characteristics and antimicrobial susceptibility of uropathogenic 
Escherichia coli strains. Genetics and molecular research 10, 4114-4125.

Osman, M.E.H., Aboshady, A.M., Elshobary, M.E., 2013. Production and characterization of antimicrobial active substance from some macroalgae collected from Abu-Qir bay (Alexandria) Egypt. African Journal of Biotechnology 12, 6847-6858.

Oxoid, 1981. The oxoid manual of culture media ingredients and other laboratory servies.. $5^{\text {th }}$ Eds.Oxoid Manual,UK.

Padmakumar, k., Ayyakkannu, k., 1997. Seasonal variation of antibacterial and antifungal activities of the extracts of marine algae from Southern coasts of India. Botanica Marina 40, 507-515.

Pushparaj, A., Raubbin, R., Balasankar, T., 2014. An antibacterial activity of the green seaweed Caulerpha sertularioides using five different solvents. International Journal Pharm Tech, Research 6, 01-05.

Ramasamy, M.S., Kumar, S.S., 2009. Antiinflammatory, antinociceptive and central nervous system depressant activities of marine bacterial extracts. Journal of Pharmacology and Toxicology 4, 152159.

Read, A., Woods, R., 2014. Antibiotic resistance management. Evolution, Medicine, and Public Health 2014, 147.

Sastry, V., Rao, G., 1995. Dioctyl phthalate and antibacterial compound from marine brown alga Sargassum wightii. Journal of Applied Phycology 7, 185-186.

Schaffera, J.N., Norsworthya, A.N., Sunb, T.T., Pearsona, M.M., 2016. Proteus mirabilis fimbriae and urease dependent clusters assemble in an extracellular niche to initiate bladder stone formation. PNAS 113, 4494-4499.

Solomon, R., Santhi, V., 2008. Purification of bioactive natural product against human microbial pathogens from marine seaweed, Dictyota acutiloba. World Journal of Microbiology and Biotechnology 24, 1747-1752.

Stickler, D.J., 2008. Bacterial biofilms in patients with indwelling urinary catheters. Nature Reviews Clinical Urology 11, 598608.

Tarchouna, M., Ferjani, A., Ben-Selma, W., Boukadida, 2013. Distribution of uropathogenic virulence genes in Escherichia coli isolated from patients with urinary tract infection. International Journal of Infectious Diseases 17, 450453.

Thomas, K.W.L., Tam, P.C., Liu, Z.K., Augustine, F.B.C., 2001 Evaluation of VITEK 2 rapid identification and susceptibility testing system against Gram-Negative clinical isolates. Journal of Clinical Microbiology 39, 2964-2966.

Vasquez, y., Hand, W., 2004. Antibiotic susceptibility patterns of communityacquired urinary tract infection isolates from female patients on the US (Texas)Mexico border.. Journal of Applied Research 4, 321-326.

Yuan, Y.V., Bone, D.E., Carrington, M.F., 2005. Antioxidant activity of dulse (Palmaria palmata) extract evaluated in vitro. Food Chemistry 91, 485-494.

\section{How to cite this article:}

Wagih A. El-Shouny, Reda M. Gaafar, Gehan A. Ismail and Marwa M. Elzanaty. 2017. Antibacterial Activity of Some Seaweed Extracts against Multidrug Resistant Urinary Tract Bacteria and Analysis of their Virulence Genes. Int.J.Curr.Microbiol.App.Sci. 6(11): 2569-2586. doi: https://doi.org/10.20546/ijcmas.2017.611.302 